\title{
Assistance in Revitalizing the Field in Ngepungsari Village, Jatipuro District, Karanganyar Regency
}

\section{Suryo Handoyo, Herman Susila, Erni Mulyandari}

University of Tunas Pembangunan Surakarta

Email: suryo.handoyo@lecture.utp.ac.id, herman.susila@lecture.utp.ac.id, erni.mulyandari@lecture.utp.ac.id.

\begin{tabular}{|c|c|}
\hline $\begin{array}{l}\text { Keywords } \\
\text { Market, Design, } \\
\text { Planning, } \\
\text { Revitalization, } \\
\text { Tourism } \\
\text { Article Info } \\
\text { Accepted: } \\
\text { February, } 2^{\text {nd }} 2022 \\
\text { Revised: } \\
\text { February, } 11^{\text {th }} 2022 \\
\text { Approved: } \\
\text { February, } 12^{\text {th }} 2022\end{array}$ & $\begin{array}{l}\text { Abstract Assistance for the Revitalization of the } \\
\text { Ngepungsari Village Field is carried out to assist the } \\
\text { community in the Ngepungsari Village, Jatipuro } \\
\text { District, Karanganyar Regency in terms of increasing } \\
\text { economic income and tourism development by } \\
\text { revitalizing the field into a tourist market. This } \\
\text { development is done independently. The difficulty } \\
\text { faced by the community in planning this field } \\
\text { revitalization is how to make a good market design } \\
\text { plan according to the needs and potential of the } \\
\text { Ngepungsari community as well as a tourist } \\
\text { destination in the village. With this market, it is } \\
\text { hoped that the villagers' produce can be sold } \\
\text { through the tourism market and at the same time it } \\
\text { can attract both domestic and international tourists } \\
\text { to Ngepungsari Village so as to increase the } \\
\text { economic income of Ngepungsari villagers. }\end{array}$ \\
\hline
\end{tabular}

\section{Introduction}

Ngepungsari Village is located in the southernmost part of Karanganyar Regency, right at the crossroads between three sub-districts, namely Girimarto District, Ngadirojo District, and Jatipuro District. 


\section{Suryo Handoyo, Herman Susila, Erni Mulyandari}

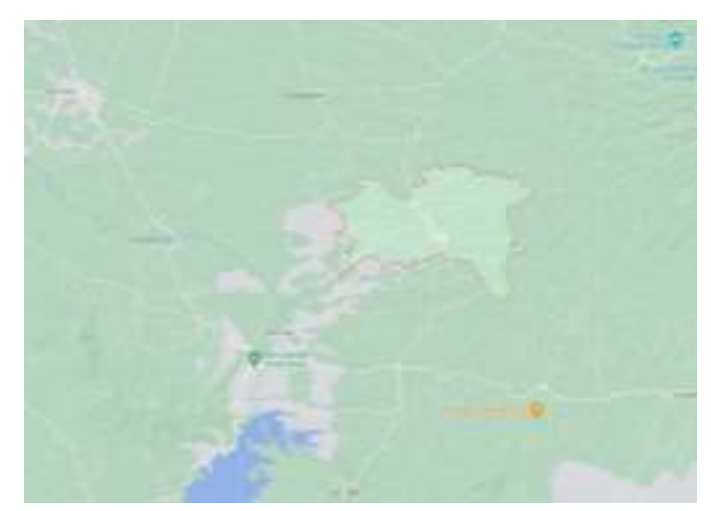

Figure 1. Location of Ngepungsari Village, Jatipuro District, Karanganyar Regency (Source: Google Maps 2021)

The village of Ngepungsari consists of the following hamlets: Jito, Kepuh, Nglasem, Ngledok, Pung Kulon, Pung Wetan, Sanan, and Talang. Most of the residents of this village are farmers and the rest are traders, civil servants (PNS), private employees, TNI, Polri and others, but when viewed from the percentage of their livelihoods, more of the villagers migrate out of town. Ngepungsari Village has agricultural products of rice, corn, soybeans, peanuts and the rest are side commodities, while the plantation products in this village are coconut and cocoa.

For educational facilities, Ngepungsari village has several schools ranging from kindergarten to elementary school. Among them are SDN 01 Ngepungsari in Kepuh, SDN 02 Ngepungsari in Nglasem, and SDN 03 Ngepungsari in Talang.

The strategic means of transportation in this village are buses and minibuses with the Solo-Wonogiri route through Karanganyar. The village area has a strategic position because it is at the meeting point of the three sub-district lines. This condition has the effect of rapid population growth, thereby increasing the mobilization of people and goods. An area where infrastructure growth is not planned can cause the process of social and economic activities of the area to be not optimal.

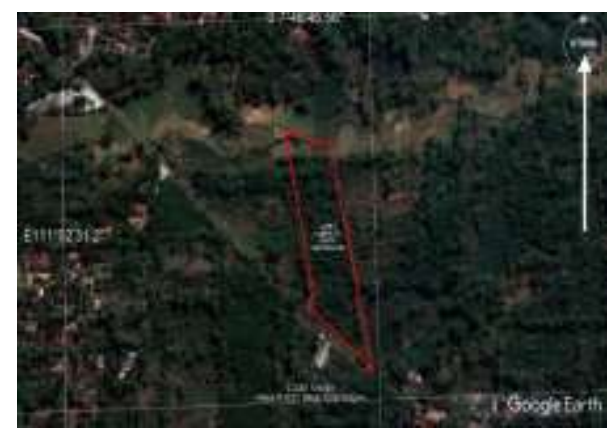

Figure 2. Location of the Ngepungsari Tourism Village Land (Source: Google Maps 2021) 
Ngepungsari village still has a lot of vacant land that is not productive but has the potential to be developed into more productive land, one of the alternative developments is the tourism market, because the strategic location of the village is at the meeting point of the three sub-districts so that with these facilities it is expected to increase the economic income of the community and the development of the tourism sector, especially in Ngepungsari Village and in Jatipuro District in general.

Ngepungsari Village has Green Open Space (RTH) which has the potential to be processed into functional green open space for the development of the tourism sector and increasing the economic income of its people. In the current condition, the green open space in Ngepungsari village is in the form of vacant land, but the land is less productive due to general constraints on management and the potential of its human resources. The community service team tries to hold discussions with related devices in order to obtain data related to the conditions and alternative solutions to these problems. There are several points of information obtained. That the Ngepungsari village officials are aware of their potential. The vacant land in Ngepungsari village can be used for activities to increase economic income and tourism in accordance with the surrounding culture. The Ngepungsari village apparatus also understands that there are changes in the internal and external conditions of society that must be considered for the common good. The Ngepungsari village apparatus has hope in the future regarding the management of the vacant land. There are obstacles from village officials regarding future solutions and methods that must be done to improve the condition of the Ngepungsari vacant land.

The Field Revitalization Assistance activity in Ngepungsari Village, Jatipuro District, Karanganyar Regency aims to identify existing problems and provide the best solution for solving these problems. The benefits that can be obtained from the Assistance for Planning for Field Revitalization in the Ngepungsari Village, Jatipuro District, Karanganyar Regency are to ease the workload of existing village officials for the benefit of the user community.

Taking into account the problems above, assistance is needed by building experts and building and area design experts who are experienced and have background knowledge in the field of Civil and Architectural Engineering.

The output targets for this activity are (1) the realization of a floor plan and contour drawing of the vacant land of Ngepungsari village, (2) the compilation of pictures of the Ngepungsari village tourism market site, (3) the compilation of detailed drawings of the Ngepungsari village tourism market plan, and (4) the compilation of method of backfilling and improving the vacant land of Ngepungsari village. 


\section{Suryo Handoyo, Herman Susila, Erni Mulyandari}

\section{Method Research}

The method of implementing community service in Ngepungsari village is carried out through three stages, namely the preparation stage, the implementation stage, and the stage of the active role of partners.

Preparation phase.

The preparation stage was carried out to conduct discussions with the Ngepungsari village apparatus about the plan for implementing community service by the Lecturer team. From this discussion, it is hoped that the correct information will be obtained. The discussion is also useful for determining the next step for the realization of the expected conditions and starting to plan steps for collecting data on vacant land and coordinating with village officials regarding regional authorities in the Ngepungsari village apparatus. The position of the community service team Lecturers are only consultants who do not have the authority to decide. The authority of the Lecturer community service team only provides constructive suggestions in a rational and measurable corridor.

\section{Implementation Stage}

Activities to be carried out at this stage are:

1. Compile measurement data and photos, as material for the analysis process.

2. Conduct a site analysis of the site conditions of the Ngepungsari vacant land location.

3. Mapping the vacant land of Ngepungsari village.

4. Conduct space analysis according to needs.

5. Create pre-design drawings in the form of site-plan drawings, floor plans and perspectives.

6. From the pre-design materials that have been prepared, discussions were held with all teams and potential users to get input and suggestions for pre-design improvements.

7. After obtaining approval of the pre-design drawing, a detailed structural drawing calculation is made for the construction implementation drawing.

8. Preparation of detailed drawings for the implementation of construction.

9. Preparation of the necessary analysis as a support.

\section{Partner Active Role Stage}

1. Discussion partners in planning the Ngepungsari tourism market.

2. Partners will be the implementers in the Ngepungsari tourism market.

\section{Result and Discussion}

\section{Preliminary survey}


Preliminary survey is an activity to get the initial information and data needed at the service location which will later be useful for further analysis. The preliminary survey for this service must go through several stages as follows.

\section{Licensing Stage}

Before conducting a preliminary survey, the service team will first provide a letter of assignment to the relevant village apparatus.

\section{Site Survey}

After submitting the assignment letter, the team plans to conduct a site survey.

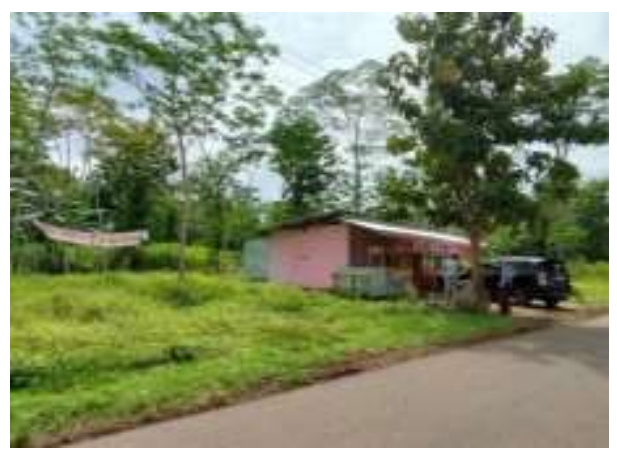

(a)

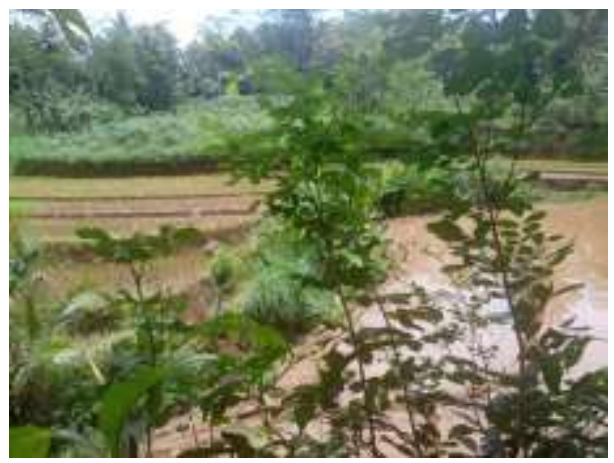

(c)

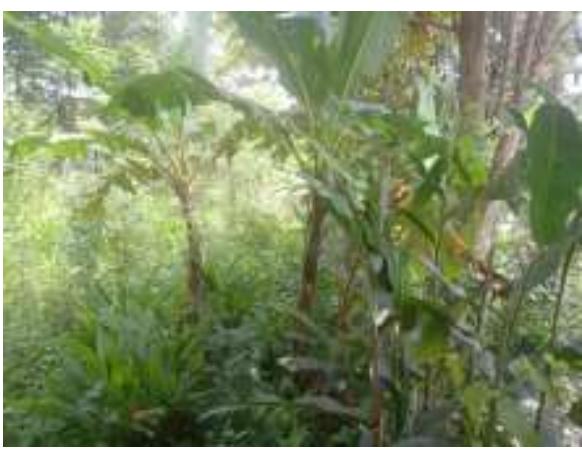

(b)

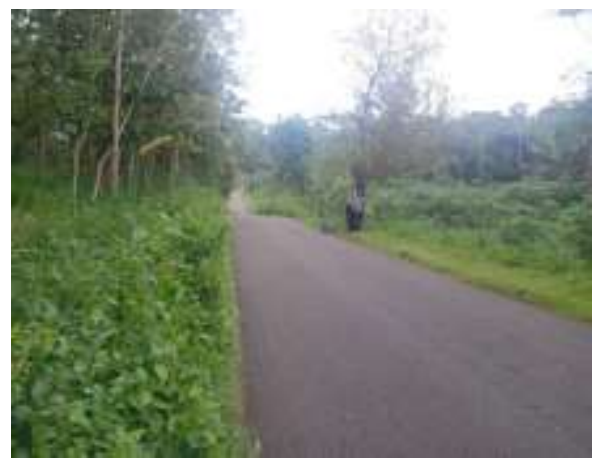

(d)

Figure 3. Locations Around Ngepungsari Village Land. (a) Front View. (b) Wild Plants on Village Land. (c) Soil Contour. (d) Road Condition.

Based on the survey results, it can be seen that there are many wild plants on the land to be planned, the contours of the land are relatively uneven, and access roads do not have adequate drainage channels.

3. Initial Discussion

Initial discussions were carried out by the Team with one of the village officials during a visit to vacant land. Based on the data from the site survey, it can be seen that there are many problems that exist in the vacant land. 


\section{Suryo Handoyo, Herman Susila, Erni Mulyandari}

4. Implementation of Mentoring

Assistance implementation activities are carried out in accordance with the activities that have been planned at the beginning, starting from compiling measurement data to preparing detailed drawings for construction implementation.

5. Preparation of Planning and Design Analysis

Based on the problems found by the Service Team, it can be concluded that the implementation of the work is divided into 2 (two) stages of work, in stage I the prioritized work items are:
a. Parking area and entrance block work
b. Drainage work on the edge of vacant land
c. Culinary and non-culinary kiosk work (SME area)
d. Manager office job
e. Multipurpose open space work

Meanwhile, for phase II the work items are prioritized on tourism facilities, including:
a. Mosque Work
b. Multipurpose building work
c. Restaurant and gazebo work
d. Fishing pond work
e. Swimming pool work and its supporting facilities
f. Self photo area work (selfie area)

Based on the discussion between the service team and the relevant apparatus, it is concluded that the current priority of work is prioritized in stage I. The results of this activity can be seen in Figure 4 and Figure 5 below.



Figure $4 \& 5$ Site Plan for the Ngepungsari Tourism Market. (a) Overall Picture. (b) Drawing Stage I 


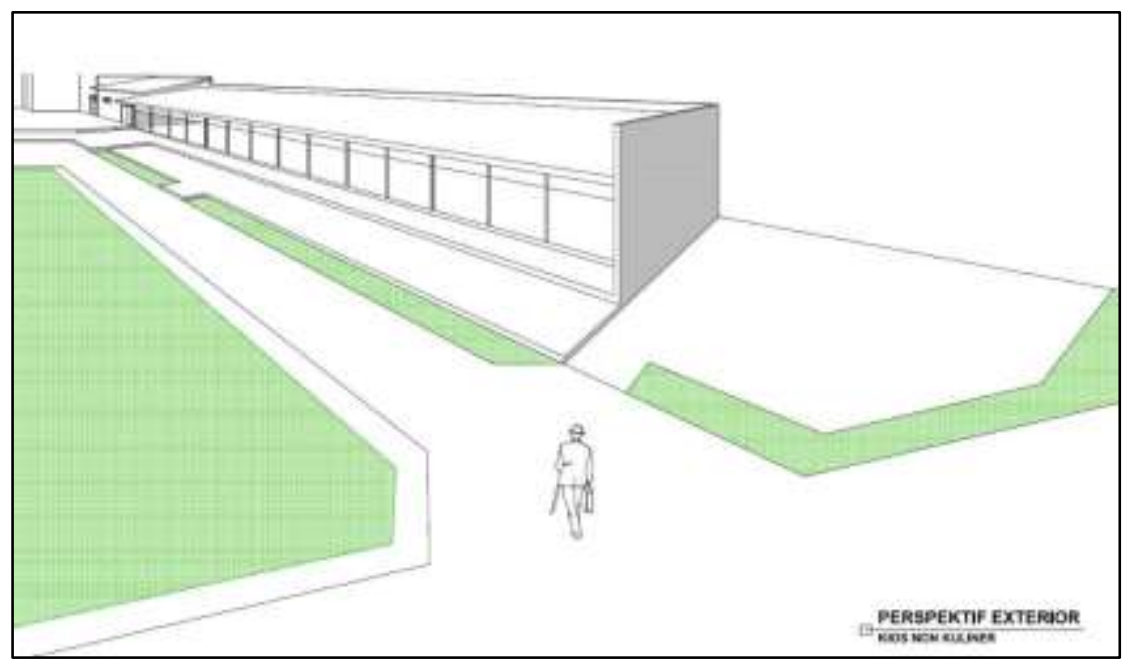

Figure 6. Picture of Non-Culinary Kiosk Exterior Perspective

\section{Conclusion}

The Community Service Team has carried out assistance in planning the design of the tourist village of Ngepungsari Jatipuro, by providing solutions to existing problems, namely:

1. Uneven soil contours are overcome by a cut and fill system (soil trimming and backfilling)

2. Plan and design tourist facilities and space requirements on the vacant land so that they are productive and function optimally.

3. Adding and allocating facilities to increase the economic income of the Ngepungsari village community in the vacant land in the form of an SME area in the form of culinary stalls and non-culinary stalls.

\section{References}

Ashihara, Yoshinobu. 1981. "Exterior Design in Architecture”.

Eckbo, Garrett,.“Urban Landscape Design”.

Hakim, Rustam 2003."Komponen Perancangan Arsitektur Lansekap, PrinsipUnsur-dan Aplikasi Disain”.Jakarta: BUMI AKSARA

Hartoyo, H. Santoni. (2018) Kriteria Ruang Publik Kalijodo Pendukung Aksesibilitas dan Peningkatan Aktivitas. Jurnal Teknik Arsitektur ARTEKS, 2, No. 2 ISSN 2541-0598 


\section{Suryo Handoyo, Herman Susila, Erni Mulyandari}

Iswanto, Danoe, (2006), “Kajian Ruang Publik Ditinjau Dari Segi proporsi Skala dan Enclosure, Jurnal Ilmiah Perancangan Kota \& Permukiman, 5 No. 2, 74-81

Simonds, John Ormsbee. 1983."Landscape Architecture, a Manual of Site Planning and Design". New York: McGraw-Hill.Inc.Simonds, John Ormsbee.1994. “Garden Cities 21, Creating a Livable Urban Environment”. New York:McGraw-Hill.Inc.

Singgih, Edi P. 2000."Ruang Berkumpul Informal bagi Warga Kampus dengan Kasus di Universitas Sebelas Maret Surakarta",Tesis S2 Jurusan Teknik Arsitektur Fakultas Teknik UGM.

Winangsih, Erna. (2010). Estetika Simbolis - Sensori Pada Ruang Publik di AlunAlun Malang. Local Wisdom Jurnal IImiah Online, 2, No.3, 20-28

Wulandari, Henny. (2014). Eksplorasi Pengalaman Panca Indera Untuk Perancangan Interior. Dimensi Interior, 12, No. 2, 85-90

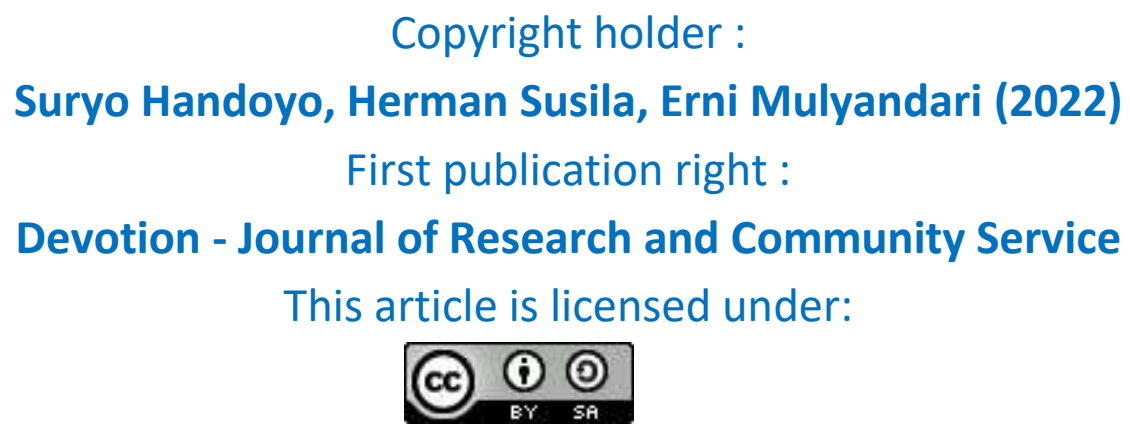

